\title{
Opioid sparing effect of low dose ketamine in patients with intravenous patient-controlled analgesia using fentanyl after lumbar spinal fusion surgery
}

\author{
Sang Ho Kim ${ }^{1}$, Soon Im Kim ${ }^{1}$, Si Young Ok${ }^{1}$, Sun Young Park ${ }^{1}$, Mun-Gyu Kim , Se-Jin Lee ${ }^{1}$, Jung Il Noh², \\ Hea Rim Chun ${ }^{1}$, and Haejin Suh ${ }^{1}$ \\ Department of Anesthesiology and Pain Medicine, ${ }^{1}$ Soonchunhyang University Seoul Hospital, Seoul, ${ }^{2}$ Soonchunhyang University \\ Bucheon Hospital, Bucheon, Korea
}

Background: The opioid sparing effect of low dose ketamine is influenced by bolus dose, infusion rate, duration of infusion, and differences in the intensity of postoperative pain. In this study, we investigated the opioid sparing effect of low dose ketamine in patients with intravenous patient-controlled analgesia (PCA) using fentanyl after lumbar spinal fusion surgery, which can cause severe postoperative pain.

Methods: Sixty patients scheduled for elective lumbar spinal fusion surgery were randomly assigned to receive one of three study medications (K1 group: ketamine infusion of $1 \mu \mathrm{g} / \mathrm{kg} / \mathrm{min}$ following bolus $0.5 \mathrm{mg} / \mathrm{kg}$, $\mathrm{K} 2$ group: ketamine infusion of $2 \mu \mathrm{g} / \mathrm{kg} / \mathrm{min}$ following bolus $0.5 \mathrm{mg} / \mathrm{kg}$, Control group: saline infusion following bolus of saline). Continuous infusion of ketamine began before skin incision intraoperatively, and continued until $48 \mathrm{~h}$ postoperatively. For postoperative pain control, patients were administered fentanyl using IV-PCA (bolus dose 15 $\mu \mathrm{g}$ of fentanyl, lockout interval of $5 \mathrm{~min}$, no basal infusion). For $48 \mathrm{~h}$ postoperatively, the total amount of fentanyl consumption, postoperative pain score, adverse effects and patients' satisfaction were evaluated.

Results: The total amount of fentanyl consumption was significantly lower in the K2 group ( $474 \mu \mathrm{g})$ compared to the control group ( $826 \mu \mathrm{g})$ and the $\mathrm{K} 1$ group $(756 \mu \mathrm{g})$ during the $48 \mathrm{~h}$ after surgery. Pain scores at rest or with movement, the incidence of adverse events and patient satisfaction were not significantly different among the groups.

Conclusions: Low-dose ketamine at $2 \mu \mathrm{g} / \mathrm{kg} / \mathrm{min}$ following bolus $0.5 \mathrm{mg} / \mathrm{kg}$ significantly reduced the total amount of fentanyl consumption during the $48 \mathrm{~h}$ after lumbar spinal fusion surgery without increasing adverse effects. (Korean J Anesthesiol 2013; 64: 524-528)

Key Words: Fentanyl, Ketamine, Pain, Postoperative.

Received: July 12, 2012. Revised: 1st, October 12, 2012; 2nd, November 13, 2012. Accepted: November 20, 2012.

Corresponding author: Soon Im Kim, M.D., Ph.D., Department of Anesthesiology and Pain Medicine, Soonchunhyang University Seoul Hospital, 22, Daesagwan-gil, Yongsan-gu, Seoul 140-743, Korea. Tel: 82-2-709-9302, Fax: 82-2-790-0394, E-mail: soonnim@schmc.ac.kr (C) This is an open-access article distributed under the terms of the Creative Commons Attribution Non-Commercial License (http:// creativecommons.org/licenses/by-nc/3.0/), which permits unrestricted non-commercial use, distribution, and reproduction in any medium, provided the original work is properly cited. 


\section{Introduction}

Patient-controlled analgesia (PCA) with opioids has been widely used for the control of post-operative pain. However, due to adverse effects such as nausea and vomiting, the adjuvant use of variable drugs has emerged [1]. Among these, ketamine, a non-competitive N-methyl-D-aspartate (NMDA) receptor antagonist, has been known to improve postoperative opioid effectiveness [2]. It has opioid sparing effect, inhibits windup and central sensitization, and reduces the development of chronic pain [3-5].

Low-dose ketamine is defined as a bolus dose of less than 2 $\mathrm{mg} / \mathrm{kg}$ when given intramuscularly or less than $1 \mathrm{mg} / \mathrm{kg}$ when administered via the intravenous (IV) or epidural route. In continuous IV administration, low-dose ketamine is defined as a rate of $\leq 20 \mu \mathrm{g} / \mathrm{kg} / \mathrm{min}[6]$.

However, the effect of low-dose ketamine is controversial [7-10]. It is thought that the method and dose of ketamine administration, and differences in the intensity of postoperative pain, may affect the results [11].

In this study, we investigated low-dose ketamine in terms of its opioid sparing effect in patients with IV PCA using fentanyl after lumbar spinal fusion surgery, which can cause severe postoperative pain.

\section{Materials and Methods}

Approval was obtained from the Institutional Review Board before study commencement. After receiving written informed consent, 60 healthy patients with an American Society of Anesthesiologists physical status classification of I-II, aged between 28 and 70 years old, and who were scheduled for elective major lumbar spinal surgery were enrolled in this randomized, placebo-controlled, double-blinded study. The type of surgery was posterior decompression and posterior lumbar interbody fusion with instrumentation.

The exclusion criteria comprised pregnancy, psychiatric problems, chronic alcoholism, drug abuse, inability to use PCA, and lack of communication ability.

Patients were randomly assigned to one of three groups: 1) $\mathrm{K} 1$ group, ketamine infusion of $1 \mu \mathrm{g} / \mathrm{kg} / \mathrm{min}$ following bolus $0.5 \mathrm{mg} / \mathrm{kg}$; 2) $\mathrm{K} 2$ group, ketamine infusion of $2 \mu \mathrm{g} / \mathrm{kg} /$ min following bolus $0.5 \mathrm{mg} / \mathrm{kg}$ of ketamine and 3) Control group, identical volume of normal saline infusion following bolus of normal saline before surgical incision. Continuous IV infusion of ketamine or saline following bolus dose started before skin incision intraoperatively, and continued until 48 h postoperatively via infusor (Autoinfusor ${ }^{\circledR}$, Ace Medical Co, Seoul, Korea), which included the relevant study medication diluted with saline. All patients and the investigators collecting the postoperative data were blinded to the randomization.

A standardized anesthesia regimen was followed. All patients received glycopyrrolate $0.2 \mathrm{mg}$ IM for premedication $30 \mathrm{~min}$ before surgery. Anesthesia was induced with propofol $2 \mathrm{mg} /$ $\mathrm{kg}$, remifentanil infusion $20 \mu \mathrm{g} / \mathrm{min}$, and rocuronium $0.6 \mathrm{mg} /$ $\mathrm{kg}$. Anesthesia was maintained with desflurane, nitrous oxide (50\%) and remifentanil infusion 5-20 $\mu \mathrm{g} / \mathrm{min}$. Approximate ten minutes before the end of surgery, a 50-100 $\mu$ g bolus dose of fentanyl and $30 \mathrm{mg}$ ketorolac were given intravenously. Ondansetron $8 \mathrm{mg}$ was IV injected simultaneously and an additional $8 \mathrm{mg}$ was mixed to PCA to prevent postoperative nausea and vomiting. After skin closure, desflurane and remifentanil were discontinued, and residual neuromuscular block was reversed with pyridostigmine and glycopyrrolate. The trachea was extubated when patients responded to verbal commands, and recovered spontaneous respiration. For postoperative pain control, patients were administered fentanyl using IV-PCA (bolus dose $15 \mu \mathrm{g}$ of fentanyl, lockout interval of 5 min, no basal infusion). After surgery, patients were observed in the postanesthetic care unit for $1 \mathrm{~h}$ before transferal to the ward.

PCA fentanyl use was evaluated for $48 \mathrm{~h}$ after surgery. The pain was evaluated with a $100-\mathrm{mm}$ visual analog scale (VAS) (0 = no pain; $100=$ worst imaginable pain). Patients were asked to evaluate their maximal degree of pain. Pain scores were recorded at rest and with movement at 1, 6, 24, and $48 \mathrm{~h}$ after surgery. Pain with movement was defined as pain on rolling, sitting, or coughing.

Adverse events such as sedation, nausea, vomiting, headache and psychomimetic symptoms (vivid dreams or hallucination) were assessed. When moderate or severe nausea or vomiting was present, patients were administered metoclopramide 10 mg or ondansetron $4 \mathrm{mg}$. Patients were also asked to rate their overall satisfaction with the PCA experience on a five-point scale (very satisfied, satisfied, neutral, dissatisfied, very dissatisfied) [12] at $48 \mathrm{~h}$ after operation.

The primary outcome measure of this study was the total amount of fentanyl consumption during the $48 \mathrm{~h}$ after operation, while the secondary outcome measures were the pain scores, adverse effects, and patient satisfaction.

Sample size was predetermined using a power analysis to achieve $90 \%$ chance $(\beta=0.1)$ with an assumed significance level of $\alpha=0.05$. From pilot study, the calculated minimum sample size was 17 patients in each group. A larger number of patients were included to allow for possible incomplete data collection or patient dropout. Data are presented as mean $\pm \mathrm{SD}$, or number of patients. The statistical analysis was performed using SPSS for Windows (version 14, SPSS Inc., Chicago, IL, USA). A one-way analysis of variance was used to compare the continuous variables among the groups. If a significant difference was noted, Bonferroni multiple comparison test was used to 
determine intergroup differences. Categorical variables were analyzed using the chi-square test or Fisher exact test, as appropriate. A P value of less than 0.05 was considered statistically significant.

Table 1. Patient Characteristics

\begin{tabular}{lccc}
\hline & $\begin{array}{c}\text { Control group } \\
(\mathrm{n}=17)\end{array}$ & $\begin{array}{c}\text { K1 group } \\
(\mathrm{n}=18)\end{array}$ & $\begin{array}{c}\text { K2 group } \\
(\mathrm{n}=17)\end{array}$ \\
\hline Sex $(\mathrm{M} / \mathrm{F})$ & $9 / 8$ & $7 / 11$ & $8 / 9$ \\
Age (yr) & $56 \pm 13$ & $57 \pm 8$ & $55 \pm 11$ \\
Weight $(\mathrm{kg})$ & $66 \pm 13$ & $60 \pm 9$ & $67 \pm 11$ \\
Operation time (min) & $186 \pm 48$ & $187 \pm 54$ & $198 \pm 36$ \\
Anesthesia time (min) & $255 \pm 50$ & $247 \pm 52$ & $265 \pm 42$ \\
Intraoperative & $1099 \pm 665$ & $1141 \pm 842$ & $1012 \pm 649$ \\
$\quad$ remifentanil use $(\mu \mathrm{g})$ & & & \\
\hline
\end{tabular}

Values are expressed as mean \pm SD or number of patients. There are no significant differences among the groups. K1 group: ketamine infusion of $1 \mu \mathrm{g} / \mathrm{kg} / \mathrm{min}$ following bolus dose $0.5 \mathrm{mg} / \mathrm{kg}$. K2 group: ketamine infusion of $2 \mu \mathrm{g} / \mathrm{kg} / \mathrm{min}$ following bolus dose $0.5 \mathrm{mg} / \mathrm{kg}$. Control group: normal saline infusion following bolus saline (equal volume and rate).

\section{Results}

Of the 60 original patients, eight were lost from the study. Five patients stopped PCA use early because of severe postoperative nausea and vomiting (two patients in control, one patient in $\mathrm{K} 1$, two patients in $\mathrm{K} 2$ ), or because of PCA use error in three patients (one patient in control, one patient in $\mathrm{K} 1$, one patient in K2). There were no significant differences among the three groups with respect to demographic data, duration of operation and anesthesia, or the total amount of remifentanil used intraoperatively (Table 1).

The total amount of fentanyl consumption was significantly lower in the K2 group ( $474 \mu \mathrm{g}$ ) compared to the control group $(826 \mu \mathrm{g})$ and the $\mathrm{K} 1$ group $(756 \mu \mathrm{g})$ during the $48 \mathrm{~h}$ after surgery $(\mathrm{P}<0.05)$ (Table 2).

VAS scores for pain at rest or with movement at 1, 6, 24 and 48 $\mathrm{h}$ postoperatively were similar among the three groups (Table 2).

No patient experienced bad dreams or hallucinations. The incidence of adverse events such as nausea, vomiting, dizziness, headache, and sedation were comparable among the groups

Table 2. Consumption of Fentanyl during $48 \mathrm{~h}$ and Visual Analogue Scale (VAS) for Postoperative Pain

\begin{tabular}{|c|c|c|c|c|}
\hline & $\begin{array}{l}\text { Control group } \\
\qquad(\mathrm{n}=17)\end{array}$ & $\begin{array}{l}\text { K1 group } \\
(n=18)\end{array}$ & $\begin{array}{l}\text { K2 group } \\
(\mathrm{n}=17)\end{array}$ & $\mathrm{P}$ value \\
\hline Total consumption of fentanyl ( $\mu \mathrm{g})$ & $826 \pm 390$ & $756 \pm 401$ & $474 \pm 264^{*}$ & 0.015 \\
\hline \multicolumn{5}{|l|}{ Resting VAS } \\
\hline $1 \mathrm{~h}$ & $71 \pm 15$ & $69 \pm 24$ & $62 \pm 23$ & 0.476 \\
\hline $6 \mathrm{~h}$ & $65 \pm 21$ & $63 \pm 22$ & $58 \pm 23$ & 0.569 \\
\hline $24 \mathrm{~h}$ & $46 \pm 23$ & $34 \pm 14$ & $39 \pm 18$ & 0.206 \\
\hline $48 \mathrm{~h}$ & $34 \pm 20$ & $29 \pm 14$ & $29 \pm 23$ & 0.713 \\
\hline \multicolumn{5}{|l|}{ Moving VAS } \\
\hline $1 \mathrm{~h}$ & $76 \pm 17$ & $75 \pm 23$ & $66 \pm 22$ & 0.349 \\
\hline $6 \mathrm{~h}$ & $74 \pm 16$ & $71 \pm 23$ & $65 \pm 22$ & 0.447 \\
\hline $24 \mathrm{~h}$ & $58 \pm 23$ & $42 \pm 16$ & $49 \pm 22$ & 0.078 \\
\hline $48 \mathrm{~h}$ & $45 \pm 19$ & $35 \pm 16$ & $37 \pm 21$ & 0.257 \\
\hline
\end{tabular}

Values are expressed as mean \pm SD. K1 group: ketamine infusion of $1 \mu \mathrm{g} / \mathrm{kg} / \mathrm{min}$ following bolus dose $0.5 \mathrm{mg} / \mathrm{kg}$. K2 group: ketamine infusion of $2 \mu \mathrm{g} / \mathrm{kg} / \mathrm{min}$ following bolus dose $0.5 \mathrm{mg} / \mathrm{kg}$. Control group: normal saline infusion following bolus saline (equal volume and rate). A one-way analysis of variance was used to compare the continuous variables among the groups with posthoc Bonferroni multiple comparison test. * $\mathrm{P}<$ 0.05 vs control group and K1 group.

Table 3. Adverse Events

\begin{tabular}{lccc}
\hline & $\begin{array}{c}\text { Control group } \\
(\mathrm{n}=17)\end{array}$ & $\begin{array}{c}\text { K1 group } \\
(\mathrm{n}=18)\end{array}$ & $\begin{array}{c}\text { K2 group } \\
(\mathrm{n}=17)\end{array}$ \\
\hline Nausea & 6 & 4 & 6 \\
Vomiting & 1 & 1 & 1 \\
Dizziness & 2 & 3 & 4 \\
Headache & 1 & 3 & 1 \\
Sedation & 1 & 0 & 1 \\
\hline
\end{tabular}

Values indicate number of patients. There are no significant differences among the groups. $\mathrm{K} 1$ group: ketamine infusion of $1 \mu \mathrm{g} / \mathrm{kg} /$ min following bolus dose $0.5 \mathrm{mg} / \mathrm{kg}$. $\mathrm{K} 2$ group: ketamine infusion of $2 \mu \mathrm{g} / \mathrm{kg} / \mathrm{min}$ following bolus dose $0.5 \mathrm{mg} / \mathrm{kg}$. Control group: normal saline infusion following bolus saline (equal volume and rate).
Table 4. Patient Satisfaction

\begin{tabular}{lccc}
\hline & $\begin{array}{c}\text { Control group } \\
(\mathrm{n}=17)\end{array}$ & $\begin{array}{c}\text { K1 group } \\
(\mathrm{n}=18)\end{array}$ & $\begin{array}{c}\text { K2 group } \\
(\mathrm{n}=17)\end{array}$ \\
\hline Very satisfied & 2 & 2 & 3 \\
Satisfied & 14 & 9 & 10 \\
Neutral & 1 & 6 & 4 \\
Dissatisfied & 0 & 1 & 0 \\
Very dissatisfied & 0 & 0 & 0 \\
\hline
\end{tabular}

Values indicate number of patients. There are no significant differences among the groups. K1 group: ketamine infusion of $1 \mu \mathrm{g} / \mathrm{kg} /$ min following bolus dose $0.5 \mathrm{mg} / \mathrm{kg}$. $\mathrm{K} 2$ group: ketamine infusion of $2 \mu \mathrm{g} / \mathrm{kg} / \mathrm{min}$ following bolus dose $0.5 \mathrm{mg} / \mathrm{kg}$. Control group: normal saline infusion following bolus saline (equal volume and rate). 
(Table 3). The patient satisfaction rate was similar among the three groups (Table 4).

\section{Discussion}

Ketamine has been used as a general anesthetic and analgesic for various pain conditions over the past several decades. Since Foster and Fagg reported the discovery of the NMDA receptor in 1987, ketamine has been used as a potential anti-hyperalgesic agent given its actions as a non-competitive NMDA-receptor antagonist. However, it remains a controversial drug due to undesirable adverse effects. It is clear that a distinction must be made between high-dose ketamine as an anesthetic agent and low-dose ketamine as an anti-hyperalgesic agent. There may even be a third dose range in which ketamine has no analgesic potency on its own but when used in combination with an opioid, yields an opioid sparing effect and superior pain relief than would occur for either drug alone [6]. There is some indication that ketamine in a dose of $0.3 \mathrm{mg} / \mathrm{kg}$ does not interfere with $\mu$-opiate receptors as, in this dose, its analgesic effects cannot be antagonized with the $\mu$-opiate antagonist naloxone [13]. Only interference with NMDA receptors may be involved in ketamine analgesia at this dose [14], suggesting that $0.3 \mathrm{mg} / \mathrm{kg}$ ketamine may be "selective" for NMDA receptors [15]. Furthermore, Tucker et al. [16] reported that low steady doses of ketamine (serum ketamine $30-120 \mathrm{ng} / \mathrm{ml}$ ) could be combined with $\mu$ opioid agonists to improve their analgesic effect without adverse effects in the clinical setting. In addition, for a ketamine infusion rate of $1-6 \mu \mathrm{g} / \mathrm{kg} / \mathrm{min}$ in combination with a loading dose, there is evidence of anti-hyperalgesic, analgesic and opioid sparing effects $[17,18]$. We therefore investigated a loading dose of $0.5 \mathrm{mg} / \mathrm{kg}$, followed by 1 or $2 \mu \mathrm{g} / \mathrm{kg} / \mathrm{min}$, as in these earlier studies.

In this study, the total amount of fentanyl used until 48 hours post-surgery was significantly lower in those patients who received ketamine infusion of $2 \mu \mathrm{g} / \mathrm{kg} / \mathrm{min}$ following $0.5 \mathrm{mg} /$ $\mathrm{kg}$ bolus dose compared to the those who received saline or ketamine infusion of $1 \mu \mathrm{g} / \mathrm{kg} / \mathrm{min}$ following $0.5 \mathrm{mg} / \mathrm{kg}$ bolus dose. This result is consistent with other studies that used a similar dose [19-22]. In contrast with this result, however, Jaksch et al. [23] reported that ketamine $2 \mu \mathrm{g} / \mathrm{kg} / \mathrm{min}$ following $0.5 \mathrm{mg} /$ $\mathrm{kg}$ bolus dose had no effect on postoperative pain reduction in patients after knee arthroscopic surgery, but this study differed from our own in that ketamine was infused for two hours postsurgery, whereas we infused for 48 hours.

Considering the short half-life of ketamine, the duration of infusion as well as the optimal dose is an important component of the opioid sparing effect. Zakine et al. [24] compared ketamine infusion during only the intraoperative period with that for the perioperative period (intraoperative plus postoperative
$48 \mathrm{~h}$ ). They demonstrated that low dose ketamine improved postoperative analgesia with a significant decrease of morphine consumption when its administration was continued until $48 \mathrm{~h}$ postoperatively.

Another result from the current study is that there was no difference in fentanyl consumption between the K1 group (ketamine infusion of $1 \mu \mathrm{g} / \mathrm{kg} / \mathrm{min}$ following $0.5 \mathrm{mg} / \mathrm{kg}$ bolus dose) and the control group. Yamauchi et al. [25] reported that continuous low-dose ketamine improved analgesic effects after cervical spine surgery but not after lumbar surgery, and indicated that the ketamine dose required for the opioid sparing effect varies by the intensity of pain. Accordingly we investigated patients who underwent posterior lumbar interbody fusion with instrumentation, which has the capacity to cause similar severe pain. We also did not use basal infusion in PCA to prevent the masking effect of ketamine from pain reduction by continuous opioid infusion.

In this study, subjects did not report any psychomimetic effects such as bad dreams and hallucinations. There were no advantages observed in terms of pain VAS and a reduction in adverse effects despite lower opioid consumption in those patients who received a ketamine infusion of $2 \mu \mathrm{g} / \mathrm{kg} / \mathrm{min}$ following $0.5 \mathrm{mg} / \mathrm{kg}$ bolus dose. As such, the opioid-sparing effect of ketamine in the clinical setting may be questionable, but may still be useful for patients who need a high dose of opioids or are unusually sensitive to opioids [11].

The central limitation of this study is that we could not use higher doses of ketamine in light of potential psychomimetic effects. Other studies have used a similar dose without reporting adverse psychiatric effects, and Schmid et al. [6] reported that the incidence of psychomimetic effects and cognitive impairment was negligible at dose less than $2.5 \mu \mathrm{g} / \mathrm{kg} / \mathrm{min}$ IV and increased with higher doses. .The purpose of this study was to find the minimum effective dose of ketamine and as such further studies that assess what represents a clinically effective dose of ketamine may be needed.

In conclusion, low-dose ketamine of $2 \mu \mathrm{g} / \mathrm{kg} / \mathrm{min}$ following bolus $0.5 \mathrm{mg} / \mathrm{kg}$, but not not $1 \mu \mathrm{g} / \mathrm{kg} / \mathrm{min}$ following bolus $0.5 \mathrm{mg} / \mathrm{kg}$, significantly reduced the total amount of fentanyl consumption during $48 \mathrm{~h}$ after lumbar spinal fusion surgery without increasing the incidence of side effects.

\section{References}

1. Kim SI, Han TH, Kil HY, Lee JS, Kim SC. Prevention of postoperative nausea and vomiting by continuous infusion of subhypnotic propofol in female patients receiving intravenous patient-controlled analgesia. Br J Anaesth 2000; 85: 898-900.

2. Yamamura T, Harada K, Okamura A, Kemmotsu O. Is the site of action of ketamine anesthesia the N-methyl-D-aspartate receptor? Anesthesiology 1990; 72: 704-10. 
3. Smith DJ, Pekoe GM, Martin LL, Coalgate B. The interaction of ketamine with the opiate receptor. Life Sci 1980; 26: 789-95.

4. Stubhaug A, Breivik H, Eide PK, Kreunen M, Foss A. Mapping of punctuate hyperalgesia around a surgical incision demonstrates that ketamine is a powerful suppressor of central sensitization to pain following surgery. Acta Anaesthesiol Scand 1997; 41: 1124-32.

5. Woolf CJ, Thompson SW. The induction and maintenance of central sensitization is dependent on N-methyl-D-aspartic acid receptor activation; implications for the treatment of post-injury pain hypersensitivity states. Pain 1991; 44: 293-9.

6. Schmid RL, Sandler AN, Katz J. Use and efficacy of low-dose ketamine in the management of acute postoperative pain: a review of current techniques and outcomes. Pain 1999; 82: 111-25.

7. Murdoch CJ, Crooks BA, Miller CD. Effect of the addition of ketamine to morphine in patient-controlled analgesia. Anaesthesia 2002; 57: 484-8.

8. Hercock T, Gillham MJ, Sleigh J, Jones SF. The addition of ketamine to patient controlled morphine analgesia does not improve quality of analgesia after total abdominal hysterectomy. Acute Pain 1999; 2 : 68-72.

9. Reeves M, Lindholm DE, Myles PS, Fletcher H, Hunt JO. Adding ketamine to morphine for patient-controlled analgesia after major abdominal surgery: a double-blinded, randomized controlled trial. Anesth Analg 2001; 93: 116-20.

10. Unlügenç H, Ozalevli M, Güler T, Işik G. Postoperative pain management with intravenous patient-controlled morphine: comparison of the effect of adding magnesium or ketamine. Eur J Anaesthesiol 2003; 20: 416-21.

11. Subramaniam K, Subramaniam B, Steinbrook RA. Ketamine as adjuvant analgesic to opioids: a quantitave and qualitative systemic review. Anesth Analg 2004; 99: 482-95.

12. Kim JA, Kim TH, Yang M, Gwak MS, Kim GS, Kim MJ, et al. Is intravenous patient controlled analgesia enough for pain control in patients who underwent thoracoscopy? J Korean Med Sci 2009; 24: 930-5.

13. Maurset A, Skoglund LA, Hustveit O, Oye I. Comparison of ketamine and pethidine in experimental and postoperative pain. Pain 1989; 36: $37-41$

14. Irifune M, Shimizu T, Nomoto M, Fukuda T. Ketamine-induced anesthesia involves the $\mathrm{N}$-methyl-D-aspartate receptor-channel complex in mice. Brain Res 1992; 596: 1-9.

15. van Berckel BN, Oranje B, van Ree JM, Verbaten MN, Kahn RS.
The effects of low dose ketamine on sensory gating, neuroendocrine secretion and behavior in healthy human subjects. Psychopharmacology (Berl) 1998; 137: 271-81.

16. Tucker AP, Kim YI, Nadeson R, Goodchild CS. Investigation of the potentiation of the analgesic effects of fentanyl by ketamine in humans: a double-blinded, randomised, placebo controlled, crossover study of experimental pain[ISRCTN83088383]. BMC Anesthesiol 2005; 5: 2.

17. Owen H, Reekie RM, Clements JA, Watson R, Nimmo WS. Analgesia from morphine and ketamine. A comparison of infusions of morphine and ketamine for postoperative analgesia. Anaesthesia 1987; 42: 10516.

18. Stubhaug A, Breivik H, Eide PK, Kreunen M, Foss A. Mapping of punctuate hyperalgesia around a surgical incision demonstrates that ketamine is a powerful suppressor of central sensitization to pain following surgery. Acta Anaesthesiol Scand 1997; 41: 1124-32.

19. Adriaenssens G, Vermeyen KM, Hoffmann VL, Mertens E, Adriaensen HF. Postoperative analgesia with i.v. patient-controlled morphine: effect of adding ketamine. Br J Anaesth 1999; 83: 393-6.

20. Javery KB, Ussery TW, Steger HG, Colclough GW. Comparison of morphine and morphine with ketamine for postoperative analgesia. Can J Anaesth 1996; 43: 212-5.

21. Kissin I, Bright CA, Bradley EL Jr. The effect of ketamine on opioidinduced acute tolerance: can it explain reduction of opioid consumption with ketamine-opioid analgesic combinations? Anesth Analg 2000; 91: 1483-8.

22. Sveticic G, Gentilini A, Eichenberger U, Luginbühl M, Curatolo M. Combinations of morphine with ketamine for patient-controlled analgesia: a new optimization method. Anesthesiology 2003; 98: 1195-205.

23. Jaksch W, Lang S, Reichhalter R, Raab G, Dann K, Fitzal S. Perioperative small-dose $\mathrm{S}(+)$-ketamine has no incremental beneficial effects on postoperative pain when standard-practice opioid infusions are used. Anesth Analg 2002; 94: 981-6.

24. Zakine J, Samarcq D, Lorne E, Moubarak M, Montravers P, Beloucif $\mathrm{S}$, et al. Postoperative ketamine administration decrease morphine consumption in major abdominal surgery: A prospective randomized double blind controlled study. Anesth Analg 2008; 106: 1856-61.

25. Yamauchi M, Asano M, Watanabe M, Iwasaki S, Furuse S, Namiki A. Continuous low dose ketamine improves the analgesic effects of fentanyl patient-controlled analgesia after cervical spine surgery. Anesth Analg 2008; 107: 1041-4. 